Journal of Applied Pharmaceutical Science Vol. 2 (10), pp. 021-025, October, 2012

Available online at http://www.japsonline.com

DOI: 10.7324/JAPS.2012.21004

ISSN 2231-3354 (cc) BY-NC-SA

\title{
Nigella sativa seeds protect against hepatotoxicity and dyslipidemia induced by carbon tetrachloridein mice
}

\author{
Amina E. Essawy ${ }^{1,2^{*}}$, Ashraf M. Abdel-Moneim ${ }^{1,3,}$ Latifa I. Khayyat $^{2}$, Aglal A. Elzergy ${ }^{1}$ \\ ${ }^{1}$ Department of Zoology, Faculty of Science, Alexandria University, Alexandria, Egypt. \\ ${ }^{2}$ Department of Biology, Faculty of Applied Sciences, Um Al Qura University, Makkah, Saudi Arabia. \\ ${ }^{3}$ Department of Biological Sciences, College of Science, King Faisal University, Al-Hassa, Saudi Arabia.
}

\section{ARTICLE INFO}

Article history:

Received on: 02/10/2012

Revised on: $16 / 10 / 2012$

Accepted on: 22/10/2012

Available online: $28 / 10 / 2012$

Key words:

$\mathrm{CCl} 4$, N. sativa,

liver enzymes,

lipid profile,

histopathology.

\begin{abstract}
The present study was conducted to evaluate the hepatoprotective effects of aqueous seed extract of Nigella sativa (black seed) on carbon tetrachloride (CCl4) induced liver damage in Swiss albino mice. CCl4 (1.9 $\mathrm{ml} / \mathrm{kg}$ b.w.) was given orally every other day for three weeks. Aqueous suspension of N. sativa seeds (50 $\mathrm{mg} / \mathrm{kg}$ b.w.) was given orally every other day alternated with $\mathrm{CCl}_{4}$ for three weeks. Blood was collected for the assessment of serum marker enzymes ( ALT, AST ,ALP and LDH) and lipid profile(triglycerides, total cholesterol, HDL and total lipids), while liver tissue was used for histopathological assessment. Serum levels of liver enzymes and lipid contents were significantly increased in animals treated with CCL4 as compared to control. Histopathological observations, also revealed severe damage in the structure of liver tissue in animals intoxicated with CCL4. Combined treatment of CCL4-exposed animals with N.sativa showed marked improvement in both biochemical and histopathological findings. Only LDH did not affect by $N$. sativa administration.
\end{abstract}

\section{INTRODUCTION}

Liver is an important body organ and is actively involved in different metabolic functions (Meyer and Kulkarni, 2001). Hepatic damage caused by chemicals (or) infectious agents is associated with distortion of these metabolic functions (Wolf, 1999; Cullen, 2005 ) and may lead to progressive liver fibrosis and ultimately cirrhosis and liver failure (Anand, 1999). However, no effective treatment that delays these complications has yet been found. Several recent studies suggest that traditional herbs and micronutrients may be useful for this purpose (Hinds et al., 1997; We et al, 2004). Carbon tetrachloride CCl4 is widely used for experimental induction of liver damage (Parola , 1992; Thrall et al. 2000). The principle causes of carbon tetrachloride (CCl4) induced hepatic damage are increased lipid peroxidation and decreased activities of antioxidant enzymes and generation of free radicals (Poli, 1993; Ohta et al., 2000).

* Corresponding Author

Prof. Dr. Amina E. Essawy

Biology Department, Faculty of Applied Sciences for Girls, Umm Al-Qura University, Mekkah, KSA
Rajesh and Latha, (2004) showed that various herbal extracts could protect organs against $\mathrm{CCl} 4$ induced oxidative stress by altering the levels of increased lipid peroxidation and enhancing the decreased activities of antioxidant enzymes. $N$. sativa is an annual herbaceous plant that belongs to the family (Ranunculaceae). It contains both fixed and essential oils, proteins, alkaloids and saponin. Thymoquinone, the major component of the essential oil, is the biologically active gradient of this plant (Ali and Blunden, 2003) . It was reported that, thymoquinone(TQ) has many medicinal properties like; anti-oxidant (Meral et al., 2001; Shalaby and khater, 2007; Zegarac et al., 2009 ), anti-inflammatory (Hajhashemi et al., 2004), anti-tumor (Banerjee et al., 2010), analgesic and other properties (Kaleem et al., 2006; Bhatti et al., 2009). On the other side, Kapoor ( 2009) proved that TQ protects hepatic tissue from deleterious effects of toxic metals such as lead, and attenuates hepatic lipid peroxidation following exposure to chemicals such as carbon tetrachloride. However, in spite of the large number of the antioxidant and hepatoprotective studies carried out worldwide on $N$. sativa oil and TQ, scrutiny of published articles (Al-Ghamdi, 2003) showed that there is a need to investigate the 
effect of whole $N$. sativa seeds, especially since traditionally the whole seeds are used for treatment in folk medicine rather than the oil extract or TQ. Therefore, the main objective of this study is to find out if aqueous extract of whole $N$. sativa seeds possesses protective effect against CCL4-induced hepatotoxicity in experimental animals.

\section{MATERIALS AND METHODS}

\section{Chemicals used}

CCl4 (98.8\% purity) was purchased from El-Nasr Pharmaceutical Chemical Company (Egypt). N. sativa seeds (black seed) were purchased from a local herb grocery (Egypt). Seeds were cleaned, air-dried and were then powdered mechanically to prepare a suspension in isotonic saline solution. The suspension (1.25 g powder of $N$. sativa $+100 \mathrm{ml}$ isotonic saline) was freshly prepared and left a few minutes before administration. Olive oil (Laboratory grade) was obtained from Sigma Chemical Co. (St. Louis, MO). It had been used as a vehicle for carbon tetrachloride.

\section{Experimental animals}

Ten weeks old laboratory male Swiss albino mice weighing about25 g each, were used. Animals were housed in plastic cages in an animal room under controlled temperature $\left(23 \pm 2^{\circ} \mathrm{C}\right)$, and $12 \mathrm{~h}$ photoperiod $(12 \mathrm{~h}$ light/dark cycle). They were given free access to a commercial pellet diet and tap water, and allowed to acclimatize for two weeks before treatment.

\section{Experimental design}

The animals were randomly divided into three groups of 10 mice each:

- Group 1: Each animal had orally received $0.9 \%$ isotonic saline solution at a dose level $4 \mathrm{ml} / \mathrm{kg}$ b.w. every other day for three successive weeks and served as a control group.

- Group 2: Each animal had orally received $\mathrm{CCl}_{4}$ at a dose level of $1.9 \mathrm{ml} / \mathrm{kg}$ b.w. (1/4LD50) mixed in olive oil every other day for three successive weeks.

- Group 3: Each animal had orally received suspension of $N$. sativa at a dose level of $4 \mathrm{ml} / \mathrm{kg} \mathrm{b.w.} \mathrm{(50} \mathrm{mg/kg} \mathrm{b.w.)} \mathrm{every}$ other day alternated with $\mathrm{CCl}_{4}$ for three successive weeks.

Twenty four hours after the end of experimental period, unanesthetized mice from both control and experimental groups were sacrificed by slaughtering. Peripheral blood samples were collected from the neck blood vessels. Serum was separated out by centrifugation at $3000 \mathrm{xg}$ for $10 \mathrm{~min}$. Serum samples were used to determine ALT, AST, ALP and LDH activities as well as lipid profile. On the other hand, the liver of each mice was promptly removed for further histopathological study.

\section{Assessment of liver enzymes and lipid contents in serum}

Liver enzymes AST, ALT, ALP, LDH and lipid profile triglycerides, total cholesterol, $\mathrm{HDL}$ and total lipids, were determined using commercially available diagnostic kits (Biomerieux SA, France).

\section{Histopathological studies}

Each sample of liver obtained was washed in saline and fixed in $10 \%$ formalin for the routine histological technique. Fixed tissues were embedded in paraffin wax, sectioned in rotary microtome ( $5 \mu \mathrm{m}$ thick) and then stained with haematoxylin and eosin (H\&E dye). At least three different sections were examined per each sample of liver. Score system was used for histopathological examinations. Vacuolar degeneration, inflammatory cell infiltration, congestion and necrosis was used as criteria. The parameters were graded as follow: $0=$ no abnormality, $+=$ mild injury, $++=$ moderate injury and $+++=$ severe injury (Murat Bilgin et al., 2011).

\section{Statistical Analysis}

The data (expressed as mean $\pm \mathrm{SE}$ ) were analyzed by one way ANOVA and LSD post hoc test using SPSS software. Values of $\mathrm{p}<0.05$ were considered to be statistically significant.

\section{RESULTS}

\section{Biochemical measurements}

Table 1 represents the effects of $\mathrm{CCl} 4$ and $N$. sativa on liver function tests. Compared with the control group, the ALT, AST, ALP and LDH activities in serum of mice treated with $\mathrm{CCl} 4$ every other day at an oral dose of $1.9 \mathrm{ml} / \mathrm{kg} \mathrm{b}$.w. were significantly elevated after three weeks. The orally administrated $N$. sativa at a dose of $50 \mathrm{mg} / \mathrm{kg}$ b.w could significantly decreased the ALT, AST and ALP activities in contrast to $\mathrm{CCl} 4$ treated mice, but $N$. sativa did not show effect on LDH activity in $\mathrm{CCl} 4$ treated mice.

Effect of $\mathrm{CCl} 4$ and $N$. sativa on blood lipid profile are presented in Table 2. CCl4 administration increased triglyceride, cholesterol, HDL and total lipids contents in serum $(\mathrm{p}<0.05)$. While treatment with $N$. sativa could significantly reduce hyperlipidemic values in $\mathrm{CCl} 4$ treated mice and restored them to control levels.

\section{Histological examinations}

Liver sections from control mice showed normal hepatic cells with well-preserved cytoplasm, prominent nucleus, nucleolus, central vein and compact arrangement of hepatocytes (Fig. 1). In contrast to this, $\mathrm{CCl} 4$ caused hydropic changes and necrosis in centrilobular hepatocytes (Fig. 2). Congestion of the central vein and sinusoids were seen with acute inflammatory cells infiltrating mainly in the central zone. The midzonal and peripheral hepatocytes showed vacuolization and fatty change (steatosis) which included the intracellular accumulation of neutral fats (Fig. 3). Derangement of hepatocyte cords were also determined. In animals treated with $\mathrm{CCl} 4$ plus $N$. sativa, tissue damage and necrosis were of less extent (Fig. 4) than the $\mathrm{CCl} 4$ group. No derangement was observed at hepatocyte cords (Fig.5). The scoring of histological damage is displayed in Table 3. 
Table. 1: Effect of $N$. sativa on $\mathrm{CCl}_{4}$ induced liver damage (mean $\pm \mathrm{SE}, \mathrm{n}=5$ )

\begin{tabular}{|c|c|c|c|c|}
\hline Group & ALT (IU/L) & AST (IU/L) & ALP (IU/L) & LDH (U/L) \\
\hline Control & $46.33 \pm 2.60$ & $88.33 \pm 18.93$ & $91.67 \pm 8.09$ & $624.33 \pm 57.89$ \\
\hline $\mathrm{CCl}_{4}$ & $198.67 \pm 11.20^{*}$ & $526.67 \pm 49.78^{*}$ & $175.33 \pm 6.89^{*}$ & $2826.67 \pm 142.52^{*}$ \\
\hline $\mathrm{CCl}_{4}+N$. sativa & $85.33 \pm 20.57^{*, \#}$ & $170.33 \pm 26.14^{*, \#}$ & $138.00 \pm 17.52^{*, \#}$ & $2304.66 \pm 250.30^{*}$ \\
\hline
\end{tabular}

$* \mathrm{p}<0.05$ compared with control

$\# \mathrm{p}<0.05$ compared with $\mathrm{CCl}_{4}$

Table 2: Effect of $N$. sativa on $\mathrm{CCl}_{4}$ induced deviation of blood lipid contents (mean $\pm \mathrm{SE}, \mathrm{n}=5$ )

\begin{tabular}{|c|c|c|c|c|c|}
\hline Group & $\begin{array}{c}\text { Triglyceride } \\
(\mathrm{mg} / \mathrm{L})\end{array}$ & $\begin{array}{c}\text { Cholesterol } \\
(\mathrm{mg} / \mathrm{L})\end{array}$ & $\begin{array}{c}\text { HDL } \\
(\mathrm{mg} / \mathrm{L})\end{array}$ & $\begin{array}{c}\text { LDL } \\
(\mathrm{mg} / \mathrm{L})\end{array}$ & $\begin{array}{c}\text { Total lipid } \\
(\mathrm{mg} / \mathrm{L})\end{array}$ \\
\hline Control & $73.33 \pm 5.24$ & $87.33 \pm 7.75$ & $34.33 \pm 1.76$ & $28.67 \pm 8.66$ & $337.66 \pm 16.71$ \\
\hline $\mathrm{CCl}_{4}$ & $157.67 \pm 10.47^{*}$ & $130.00 \pm 5.13^{*}$ & $67.34 \pm 2.60^{*}$ & $40.67 \pm 7.62^{*}$ & $600.33 \pm 27.14$ \\
\hline $\mathrm{CCl}_{4}+N$. sativa & $88.34 \pm 12.86^{\#}$ & $102.22 \pm 2.84^{\#}$ & $42.66 \pm 2.60^{\#}$ & $31.33 \pm 2.18$ & $420.00 \pm 17.61^{\sharp}$ \\
\hline
\end{tabular}

$* \mathrm{p}<0.05$ compared with control

$\# \mathrm{p}<0.05$ compared with $\mathrm{CCl}_{4}$

Table. 3: Semiquantitive score of histopathological findings

\begin{tabular}{|c|c|c|c|c|c|}
\hline Group & $\begin{array}{c}\text { Hydropic } \\
\text { degeneration }\end{array}$ & Liver steatosis & $\begin{array}{c}\text { Inflammatory cell } \\
\text { infiltration }\end{array}$ & Congestion & Necrosis \\
\hline Control & 0 & 0 & 0 & 0 & 0 \\
\hline $\mathrm{CCl}_{4}$ & +++ & ++ & +++ & +++ & +++ \\
\hline $\mathrm{CCl}_{4}+N$. sativa & + & 0 & + & ++ & + \\
\hline
\end{tabular}

Damage grade are as follow: 0 (absent), + (mild), ++ (moderate) and +++ (severe).

$0=$ no abnormality,$+=$ mild injury,$++=$ moderate injury and $+++=$ severe injury.

The livers of ten animals in each group were examined.

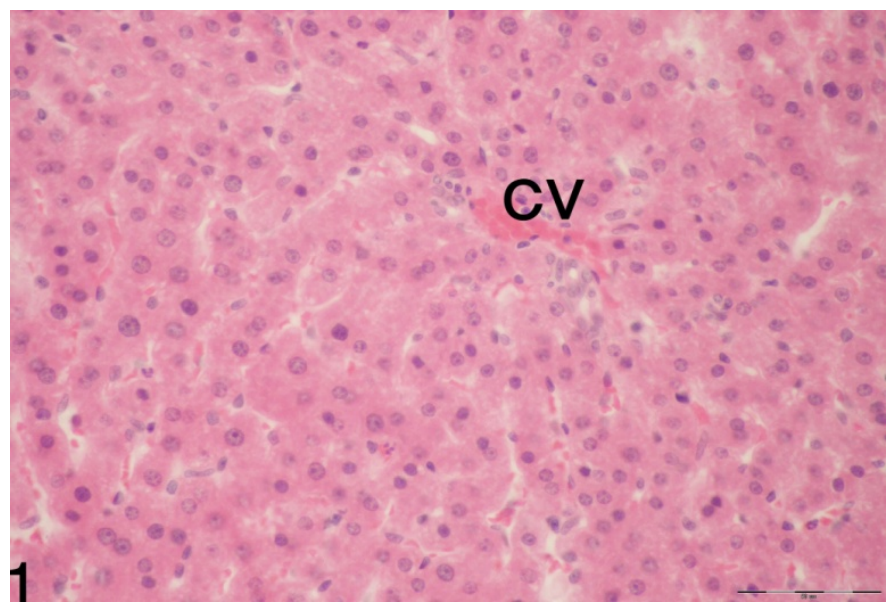

Fig. 1: Control mouse liver showing no pathological changes in which the normal hepatic cells are arranged in cords separated by widened sinusoids. CV $=$ central vein. Scale bar: $50 \mu \mathrm{m}$.

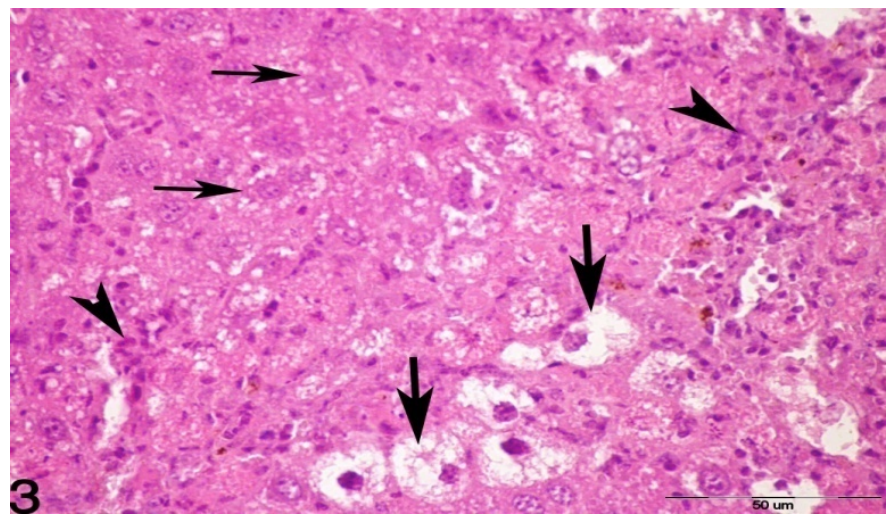

Fig. 3: Section of intoxicated mouse liver with $\mathrm{CCl}_{4}$ showing hepatocellular damage (thick arrows), aggregations of inflammatory cells (arrowheads), and liver steatosis (thin arrows). Scale bar: $50 \mu \mathrm{m}$.

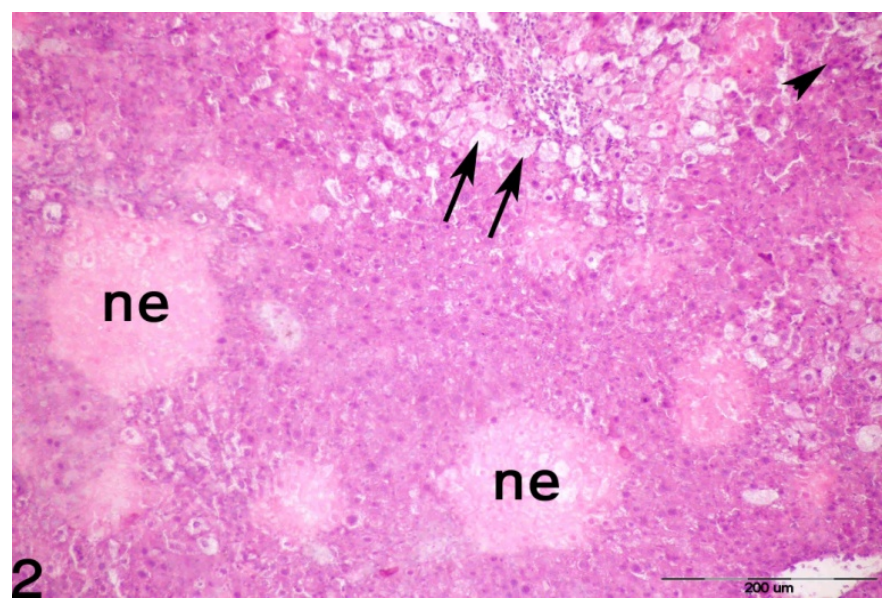

Fig. 2: Section of intoxicated mouse liver with $\mathrm{CCl}_{4}$ showing hydropic degeneration (arrows), lymphocyte infiltration (arrowhead), and necrosis (ne) Congestion of central vein can be noted. Scale bar: $200 \mu \mathrm{m}$.

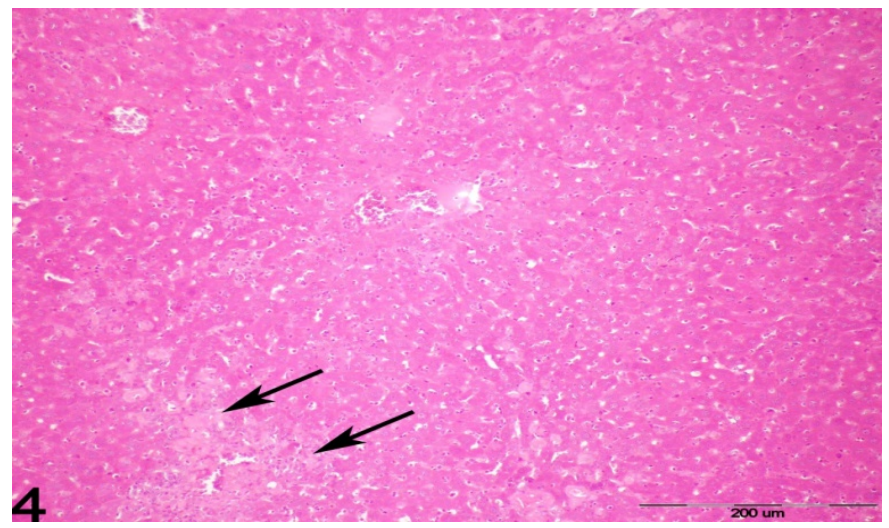

Fig. 4: Section of $\mathrm{CCl}_{4}+N$. sativa treated mouse showing improvement in the liver tissue. Arrows indicate focal hepatocellular necrosis. Scale bar: $200 \mu \mathrm{m}$. 


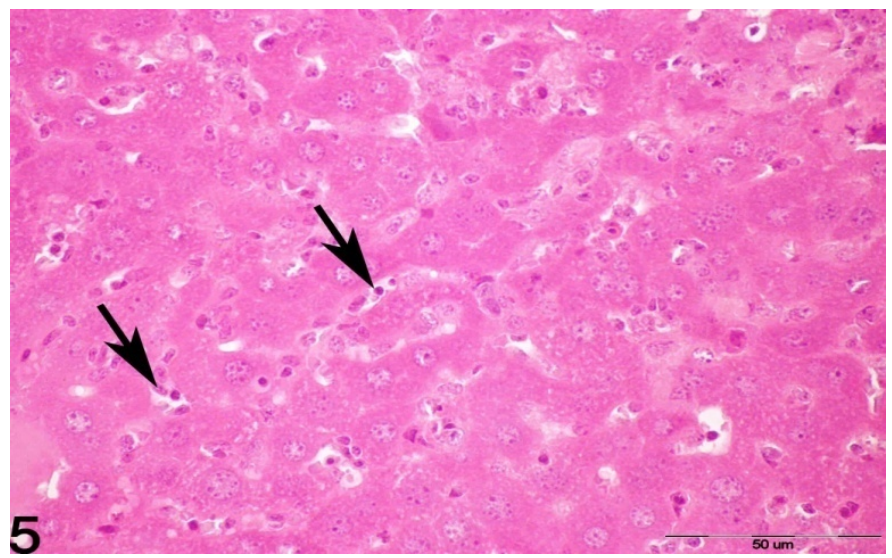

Fig 5: Section of $\mathrm{CCl}_{4}+N$. sativa treated mouse showing significant liver protection as evident by the presence of normal hepatic cords with moderated sinusoidal congestion (arrows), few inflammatory cells and absence of liver steatosis. Scale bar: $50 \mu \mathrm{m}$.

\section{DISCUSSION}

This study was undertaken to demonstrate the protective ability of aqueous suspension of $N$. sativa seeds against liver damage induced by $\mathrm{CCl} 4$ in Swiss albino mice.

In the current work, damage of the liver caused by $\mathrm{CCl} 4$ was evident by the alteration in serum marker enzymes and lipid profile concentrations beside the histopathological changes in liver tissue. Administration of CCL4 significantly increased the serum levels of liver enzymes (AST, ALT, ALP) and LDH, which are indices of liver cell damage and leakage of enzymes from cells ( Rajesh \& Latha, 2004 ; Bashandy \& Al Wasel, 2011). Ravikumar et al., (2005) reported that, rise in ALT activity is almost always due to hepatocellular damage and is usually accompanied by rise in AST and ALP.

CCL4 is found to produce free radicals, which affect the cellular permeability of hepatocytes leading to elevated levels of liver enzymes (Kumar et al., 2009). On the other hand, the activity of serum lipid profile such triglycerides, total cholesterol, HDL and total lipids was elevated, and this indicates deterioration in hepatic function due to the damage caused by $\mathrm{CCl} 4$ administration.

Histopathological studies also support the biochemical analysis. Examination of liver sections of mice received CCL4 revealed disruption of the normal structural organization of the hepatic lobules and loss of the characteristic cord-like arrangement of the normal liver cells.. Many hepatic cells were damaged and lost their characteristic appearance while others showed marked cytoplasmic vacuolization. The nuclei of these cells were pyknotic. Leukocyte infiltration and fatty deposition were also evident. Previous results showed that, CCL4 induced centrilobular hepatocellular vacuolar degeneration and necrosis (Trivedi \& Mowat, 1983; Berman et al., 1992 ; Brandao et al. 2000). The CCL4 induced hepatotoxicity has been referred to the excessive formation of free radicals formed during its detoxification in the hepatocytes smooth endoplasmic reticulum by the cytochrome P450 (Wang et al., 1997). Balahoroglu et al. (2008) reported that production of lipid peroxidation induced by CCL4 may lead to changes in biological membranes which result in serious cellular injury in liver.

Treatment with $N$. sativa seeds significantly declined the effects of $\mathrm{CCl} 4$ induced damage and it was evidenced by the decreased level of liver enzymes and lipid profile and restoration of hepatocellular architecture.

Similarly, Al-Razzuqi et al. (2011) had reported protective effect of oil extract of $N$. sativa seeds against carbon tetrachloride induced acute liver injury in experimental rabbit models. Also, protective effect of black seed oil against lead acetate-induced hepatic tissue damage in mice was investigated (Alarifiet al., 2o12). Thymoquinone, the active constituent of $N$. sativa, has been well documented as a potent antioxidant, particularly against the CCl4-induced free radical species (AlGhamdi , 2003 ). Thymoquinone prevents the formation of toxic stable complex by a combination of $\mathrm{CCl} 3 \mathrm{O} 2$ free radical and the glycolipid component of cell membrane, and therefore restores cellular architecture and prevents the leakage of its enzymes. (AlAli et al., 2008).

The present bio-chemical and histological results proved that Nigella sativa seeds possess potential to protect the liver tissue against oxidative damages and could be used as an effective protector against $\mathrm{CCl} 4$ induced liver damages.

\section{REFERENCES}

Alarifi, S., Aldahmash,B., El-Nagar, D. and Dkhil, M. Effect of corn oil, flaxseed oil and black seed oil on lead acetate-induced hepatic tissue damage: A histological study. J Med Plants Res. 2012; 6(24): 41284134

Al-Ghamdi,M. Protective Effect of Nigella sativa Seeds Against Carbon Tetrachloride-induced Liver Damage.The American Journal of Chinese Medicine. 2003; 31( 5): 721-728

Al-Ali, A., Alkhawajah, A., Randhawa, M. and Shaikh, N. Oral and intraperitoneal LD50 of thymoquinone, an active principle of Nigella sativa, in mice and rats. J. Ayub. Med. Coll. Abbottabad. 2008 ; 20(2): 2527

Ali B. and Blunden G. Pharmacological and toxicological properties of Nigella sativa. Phytother Res. 2003; 17: 299-305

Al-Razzuqi, R. Hussaini,J. and Al-Jeboori, A. Protective effect of Nigella sativa against carbon tetrachlorideinduced acute liver injury in experimental rabbit models. Int J Green Pharm. 2011; 5(3): 198-200.

Anand, B. Cirrhosis of liver. West L Med. 1999; 171:110-115.

Balahoroglu R., Dulger H., Ozbek H., Bayram I. and Sekeroglu, M. Protective effects of antioxidants on the experimental liver and kidney toxicity in mice. Eur J Gen Med. 2008; 5 (3): 157-164.

Banerjee S., Azmi A., Padhye S., Singh M., Baruah J., Philip P., Sarkar F. and Mohammad, R. Structure-activity studies on therapeutic potential of Thymoquinone analogs in pancreatic cancer. Pharm. Res. 2010; 27: 1146-1158.

Bashandy, S. and Al Wasel,S. Carbon tetrachloride-induced hepatotoxicity and nephrotoxicity in rats: Protective role of vitamin C. Journal of pharmacology and Toxicology. 201; 1 6(30): 283-292.

Berman E., House D., Allis J. and Simmons J. Hepatotoxic interactions of ethanol with allyl alcohol or carbon tetrachloride in rats. $\mathbf{J}$. Toxicol. Environ. Health. 1992; 37(1): 161-176

Bhatti I., UrRehman F., Khan M. and Marwat, S. Effect of Prophetic Medicine Kalonji (Nigella sativa L.) On Lipid Profile of Human Beings: An In vivo Approach. J, World Appl. Sci. 2009; 6(8): 1053-1057.

Brandao, C., Ferreira, H., Piovesana, H., Polimeno, N., Ferraz, J., DE Nucci, G.(2000): Developmental model of liver cirrhosis in rabbits. Clin Exp Pharma Physiol. 2000; 27: (12): 987-990. 
Cullen J. Mechanistic classification of liver injury. Toxicol Pathol 2005; 33: 6-8

Hajhashemi, V., Ghannadi, A., Jafarabadi ,H. Black cumin seed essential oil, as a potent analgesic and antiinflammatory drug. Phytother. Res. 2004; 18(3): 195-199

Hinds, T., Wesk, W., Knight, E. Carotenoids and retinoids: A review of research, clinical and public health applicationsz. clin pharmacol. 1997; 37: 551-8.

Kaleem M, Kirmani D, Asif M, Ahmed Q, Bano B Biochemical effects of Nigella sativa $\mathrm{L}$ seeds in diabetic rats. Indian J. Exp. Biol . 2006; 44(9): 745-748

Kapoor, S. Emerging clinical and therapeutic applications of Nigella sativa in gastroenterology. World J. Gastroenterol. 2009; 15: 2170- 2171.

Kumar,P., Sivaray,A. ,Elumalai,E. and Kumar,B. Carbon tetrachloride - induced hepatotoxicity in rats - protective role of aqueous leaf extracts of Coccinia grandis. International Journal of Pharm Tech Research. 2009; 1(4): 1612-1615.

Meral, I., Yener, Z., Kahraman, T. and Mert, N. Effect of Nigella sativa on glucose concentration, lipid peroxidation, anti-oxidant defence system and liver damage in experimentally-induced diabetic rabbits. J. Vet. Med. Physiol. Pathol. Clin. Med.2001; 48(10): 593-599

Meyer, S. and Kulkarni, A. Hepatotoxicity. In: Introduction to biochemical toxicology. 3rd Edn. Newyok: John Wiley and Sons. 2001; P. 487

Murat Bilgin, H., Atmaca, M., Deniz Obay, B., Ozekinci, S., Taşdemir, E. and Ketani, A. Protective effects of coumarin and coumarin derivatives against carbon tetrachloride-induced acute hepatotoxicity in rats. Exp Toxicol Pathol. 2011; 63(4): 325-330.

Ohta, Y., Kongo, M., Sasaki, E., Nishida, K., and Ishiguro, I. Therapeutic effect of melatonin on carbon tetrachloride-induced acute liver injury in rats. J. Pineal Res.2000; 28:119-126

Parola M, Leonarduzzi G, Biasi F, Albano E, Biocca ME, Poli G, Dianzani MU. Vitamin E dietary supplementation protects against carbon tetrachloride-induced chronic liver damage and cirrhosis. Hepatology . 1992 ; 16: 1014-1021
Poli, G.: Liver damage due to free radicals. Br Med bull. 1993; 49:604-20

Rajesh, M. and Latha,M. Perliminary evaluation of the antihepatotoxic activity of Kamilari, a polyherbal formulatio. J. Ethnopharmacol.2004; 91: 99-104.

Ravikumar ,V., Shivashangari, K. and Devak,i T. Hepatoprotective activity of Tridax procumbens against dgalactosamine/ lipopolysaccharide-induced hepatitis in rats. J. Ethnopharmacol.2005; 101: $55-60$.

Shalaby, M. and Khater, O. Hepatoprotective and antioxidant effects of Nigella sativa oil on carbon tetrachloride induced liver damage in rats. J. Faculty Home Economic, Minufiya University. 2007; 16:32-41

Thrall, K., Vucelick, M., Gies, R., and Benson, J. Comparative metabolism of carbon tetrachloride in rats, mice, and hamsters using gas uptake and PBPK modeling. J. Toxicol. Env. Health. 2000; 60A:531-548

Trivedi, P. and Mowat, A. Carbon tetrachloride-induced hepatic fibrosis and cirrhosis in the developing rat: an experimental model of cirrhosis in childhood. Br. J. Exp. Pathol. 1983; 64(1): 25-33

Wang, P., Kaneko, T., Tsukada, H., Nakano, M., Nakajima, T. and Sato, A. Time courses of hepatic injuries by chloroform and by carbon tetrachloride comparison of biochemical and histopathological changes. Arch Toxicol.1997 ; 71: 638-45

We, Y., Liu, D., Ding, L., Liq, Xiao, Y. Therapeutic effects and molecular mechanical of antifibrosis herbs and selection on rats with hepatic fibrosis. World. J Gastroenterol. 2004; 10:703-6.

Wolf, P. Biochemical diagnosis of liver disease. Ind. J. Clin. Biochem. 1999; 14: 59-64.

Zegarac, J., Stipcevic, T., Belscak, A. (2009): Antioxidant properties and phenolic content of different floral origin honeys. J. ApiProd. Apimed. Sci.2009; 1(2): 43-50.

\section{How to cite this article:}

Amina E. Essawy Ashraf M. Abdel-Moneim' Latifa I. Khayyat, Aglal A. Elzergy. Nigella sativa seeds protect against hepatotoxicity and dyslipidemia induced by carbon tetrachloride in mice. J App Pharm Sci. 2012; 2 (10): 021-025. 